\title{
O que um jornal pode contar sobre uma organização? Análise do Jornal Política Operária. 1962-1965.
}

\section{CAIO LIMA DE OLIVEIRA CARVALHO}

\author{
Bolsista PIBIC/PROBIC/UEFSCNPQ, Graduando em História, Universidade Estadual de Feira de Santana, e-mail: \\ carvalhocaio01@gmail.com \\ Eurelino Teixeira Coelho Neto, Departamento de Ciências Humanas e Filosofia, Universidade Estadual de Feira de \\ Santana, e-mail: eurecoelho@uefs.br
}

\section{PALAVRAS-CHAVE: Esquerda, POLOP. Ditadura.}

\section{INTRODUÇÃO}

O presente trabalho debruçou-se sobre a análise da atividade de propaganda política realizada pela Organização Revolucionária Marxista - Política Operária (Polop) durante o período de 1962-1965. Na época que o Brasil passou pela Ditadura Civil Militar (1964-1985), a Polop cumpriu importante papel dentro deste cenário. Em um contexto internacional polarizado entre as potencias estadunidense e soviética, vários países participaram de intensa atividades políticas associadas de algum modo à situação internacional. Nosso objetivo foi identificar e analisar a estrutura do Jornal, suas seções, autores, linguagens. Analisar a propaganda da organização a partir dos temas abordados, identificar as direções propostas ao proletariado brasileiro como soluções, caminhos e alternativas para as questões que apareciam naqueles anos.

\section{MATERIAL E MÉTODOS OU METODOLOGIA (ou equivalente)}

A pesquisa baseia-se em análise documental e dispõe, para tanto, da coleção em poder do LABELU. Este corpus compõe-se de aproximadamente 1500 peças organizadas provisoriamente em cinco categorias, sendo essas: Teses Nacionais; Teses Gerais (internacionais); Periódicos (Política Operária, Marxismo Militante, Brasil Socialista, Teoria e Prática); Documentos de circulação interna (Boletins nacionais, Tribuna de debates, Circulares, Cadernos da Esquerda Revolucionária, Curso Básico); Documentos internacionais (vínculos internacionais da PO).

\section{RESULTADOS E/OU DISCUSSÃO (ou Análise e discussão dos resultados)} Jornais sempre foram veículos de propaganda considerados prioritários pelas organizações de esquerda. Além disso, na década de 1960, provavelmente um jornal seria o melhor caminho que uma organização com limitações de pessoas e de orçamento conseguiria para atingir o máximo de pessoas possíveis. Esse foi o meio que a Polop escolheu, mas com quais objetivos? Com o objetivo de definir um programa de ação ${ }^{1}$, isso porque a organização acreditava que:

A velha esquerda, que já teve um papel significativo nas lutas do passado, gastou-se e mostrou-se incapaz de acompanhar 0 desenvolvimento do que tanto fala. Hoje não consegue mais galvanizar a nova geração destinada a continuar a obra. ${ }^{2}$

\footnotetext{
${ }^{1}$ Jornal Política Operária. №01 Pág. 01 Ano: 1962.

2 idem
} 
Em sua primeira fase, de que nos ocupamos aqui, o jornal Politica Operária tem sua primeira publicação em janeiro de 1962 e sua última em janeiro de 1964, totalizando 8 publicações o que dá uma média de uma publicação a cada 3 meses. No ano de 1962 foram publicados 4 números, em 1963 mais 3 publicações e a última publicação em janeiro de 1964. A estrutura do jornal passa por mudanças. Na sua primeira edição ele tem a estrutura de um jornal de bancas, como são comercializados até hoje, com uma capa bem chamativa, que apresenta o sumário ao leitor, uma foto de Fidel Castro e a frase principal no topo da capa: "Por uma frente única dos trabalhadores da cidade e do campo". Essa estrutura continua nos números 02 e 03, mas no numero 04 ele ganha um corpo de revista, sem capas e a impressão no formato de página A4. Esse formato fica até o número 07 , o último jornal que analisamos, o de número 08 retorna realmente ao formato de jornal como conhecemos.

A organização deixa evidente durante o jornal que pensa a conjuntura brasileira como parte de todo conjuntura internacional. Estão sempre presentes análises de outros países, principalmente da URSS e de ações dos EUA, na época as duas potências mundiais. Existe também um recorte bem explicito para a América Latina, a situação do continente sempre é abordada, em alguns números antes de matérias sobre outros continentes. A narrativa construída é de que a situação do Brasil em grande parte tem relação com o capitalismo no mundo como um todo e que devemos buscar bons exemplos lá fora de luta e enfrentamento em busca da revolução, mas sem implementar do mesmo jeito aqui no Brasil. As matérias sempre mostram que tal forma de luta deu certo em algum lugar, mas aponta o motivo que poderia dar resultados diferentes se aplicada aqui. Por isso a necessidade da construção coletiva do caminho para revolução Brasileira e por acreditar nessa perspectiva é que o carro chefe de alguns editoriais, incluindo o número 01 publicado em 1962 sobre alternativas ao Brasil, insistiam não somente no sentido de que a organização estava defendendo o caminho certo, mas quase que pedindo uma autocrítica do que outras organizações defendiam.

Existe certo destaque para a região Nordeste. $\mathrm{O}$ jornal de número 03 , trás na capa "Paraíba: Não se mata camponês impunemente. " O número 02 já trazia uma matéria com titulo "problemas do movimento camponês do Nordeste" e nos jornais seguintes a pauta de camponeses já passa a ganhar corpo, como 
no número 04 uma matéria de Paulo Singer: "A luta dos camponeses no Brasil”. O estado de São Paulo, grande centro do proletariado brasileiro, também tem destaque em alguns jornais. A primeira vez que a Polop fala em greve é no jornal 01 com a matéria "a greve em São Paulo", nessa matéria já podemos perceber como a organização acredita que o proletariado brasileiro está muito mal preparado:

"Impõe-se, de imediato, a constatação do despreparo que caracterizou o movimento. A direção da greve, malgrado as claras ameaças feitas pelas autoridades civis e militares, foi apanhada de surpresa pela violenta repressão."3

No número 02 o Estado de São Paulo volta a aparecer agora com a matéria “Operário em São Paulo já sabem em quanto são explorados”. No Brasil, os lugares que mais recebem destaque são esses, o jornal destaca outros países, como URSS, EUA, Cuba e Argélia.

A Polop ficou conhecida por sua inserção no meio estudantil, principal em universidades, mas, apesar dessa forte inserção, o tema de Universidade praticamente não aparece Somente uma vez tem espaço no jornal de número 04, com a matéria: "Reforma Universitária: Questão Política" escrita por Emir Sader. Essa matéria é basicamente uma análise do livro de Álvaro Vieira Pinto, "A questão da universidade" que é o primeiro livro lançado pela editora da UNE. Após debater a obra e seus pontos, Emir Sader conclui demostrando a opinião da Polop sobre Universidades:

"A Universidade não é fator constante do quadro social por qualquer eventualidade. Ela é fechada às camadas populares, exatamente, porque faz parte da totalidade de contexto socioeconômico que a gera. Como expressão da superestrutura de um regime."4

O tema estudantil quando aparece no Jornal, é quase que sempre ligado à União Nacional dos Estudantes (UNE), seja com movimentações que estejam ocorrendo na entidade como eleições, ou com propostas para a entidade como no número 04 com a CPC: Frente Única Estudantil. Um momento que o tema ganha destaque com proposições da organização é na matéria de Vânia Bambirra "Novo impulso para o Movimento Estudantil" também no número 04.

De todos os temas que aparecem no jornal, sobressaio foco central da teoria revolucionária formulada pela organização, isto é, que o Brasil já tinha um proletariado suficiente para uma revolução socialista $A$ Polop, através do seu

\footnotetext{
${ }^{3}$ Jornal Política Operária № 01. Pág. 03. Ano: 1962

${ }^{4}$ Jornal Política Operária No 04. Pág. 33. Ano 1962.
} 
jornal, busca demonstrar caminhos para a revolução socialista sem a necessidade de aliança com a burguesia nacional, desde o primeiro número já conseguimos ver como veem a conjuntura do Brasil e a força que a classe operária já tem

\section{CONSIDERAÇÕES FINAIS (ou Conclusão)}

Desta forma, podemos concluir que a criação do Jornal Política Operária, foi uma, dentre outras funções, tentativa da Polop de mostrar para o proletariado brasileiro que o mesmo já tinha condições próprias de fazer a sua revolução sem aliança com a burguesia. O jornal também cumpriu o papel de passar a direção da organização para todos os militantes.

\section{REFERÊNCIAS}

OLIVEIRA, Joelma Alves de. POLOP: As origens, a coesão e a cisão de uma organização marxista (1961-1967). Dissertação de mestrado. UNESP. Araraquara, 2007 BANDEIRA, Moniz. O Caminho da Revolução Brasileira. Rio de Janeiro, MELSO, 1962. COELHO, Eurelino. Dissonâncias à esquerda: a POLOP, o golpe e a ditadura militar. In: MATTOS, Marcelo Badaró e VEGS, Rubén (orgs.) Trabalhadores e Ditaduras: Brasil, Espanha e Portugal. Rio de Janeiro, Consequência, 2014.

FICO, Carlos. Ditadura Militar Brasileira. Aproximações teóricas e historiográficas. Revista Tempo e Argumento, Florianópolis, v. 9, n. 20, p. 05- 74. jan./abr. 2017

GORENDER, Jacob. Combate nas Trevas. A esquerda brasileira: das ilusões perdidas à luta armada. $4^{\mathrm{a}}$ ed., São Paulo, Ática, 1990

MATTOS, Marcelo Badaró. Em busca da revolução socialista: a trajetória da POLOP (1961-1967). In: RIDENTI, Marcelo e REIS FILHO, Daniel Aarão (orgs.). História do Marxismo no Brasil vol. V. Campinas, Edunicamp, 2002 